\title{
Self-Actualization among College Students: A Study With Reference To Sex, Place of Living and Medium of Teaching
}

\author{
Trupti Ambalal Chandaliya
}

\begin{abstract}
ABATRACT
The main purpose of this research was to effect the self-actualization among college students. The total sample consisted of 320-college students selected randomly from various college of Rajkot district. The research tool for self-actualization was measured by Dr. K. N. Sharma selfactualization inventory (SEAI) was used. Here ' $F$ ' test was applied to check the significance difference of college students. The study revealed that there was significant difference between male and female of college students. It was observed that the male college students less selfactualization than female college students.
\end{abstract}

Keywords: Self-actualization and college students.

\section{INTRODUCTION:}

The one word which best characterizes adolescence is "change". The changes are physiological, sociological and psychological. Self-actualization is the term used to define the modern psychological concept which was first coined by Kurt Goldstin (1934) and then developed by Maslow (1943).

The African union defines youth as "person" and the world health organizations (WHO), identifies youth as those between 10 and 19 years (USAID, 2012). Maslow's hierarchy, at the bottom with psychological needs and progress to safety needy needs self-esteem and finally the need for self-actualization. The implication of the fulfillment of these lower needs suggests that the self-actualization, person longer has the "need" for these motivational drives. Such an individual would subsequently press particular characteristics, which were observed and studied by Maslow (1968). Thus we have a description of "self-actualizing individual" but the path to achieve this stage could not explained by Maslow hierarch.

Hah \& yang souk (1994) self-actualization level depends on motivation of choice, satisfaction with nursing as a major and satisfaction with college life. There for and effective guidance program is required to improve motivation and satisfaction with nursing as a major and which college life.

${ }^{1}$ Research Scholar, Department of Psychology, Saurashtra University, Rajkot

(C) 2015, T Chandaliya; licensee IJIP. This is an Open Access Research distributed under the terms of the Creative Commons Attribution License (http://creativecommons.org/licenses/by/2.0), which permits unrestricted use, distribution, and reproduction in any Medium, provided the original work is properly cited. 


\section{Self-Actualization among College Students: A Study With Reference To Sex, Place of Living and Medium of Teaching}

Irena Pufal Struzik (1995), self-actualization in gifted in aggressive young people. There was a trend towards higher self-actualization among gifted students and a need for stimulation and varied experience. The assumption that lower anxiety and higher self-acceptance are characteristic of young people with higher self-actualization was not conformed which suggests that there is a need to intensify parents' and teachers' support for student coping with difficulties.

What a man can be, he must be. This forms basis of the perceived need for self-actualization. This level of need pertains of what: a person's full potential is, and realizing that potential. Maslow describes the desire as the desire to become more and more what one is, to become everything that one is capable of becoming. This is a broad definition of the need for selfactualization but when applied to individuals, the need is specific. For example one individual may have the strong desire to become an ideal parent, in another it may be expressed athletically, and in another it may be expressed in painting, pictures or inventions. In order to reach a clear understanding of this level of need one must first not only achieve the previous needs, physiological, safety, love and esteem, but master these needs. Below are Maslow's descriptions of a self-actualization. Parson's different needs and personality traits.

Goldstein's critique of refried metaphors and subordinate drives are persuasive, but where does he leave us in understanding motivation? The concept of self-actualization is not without its own problems. What is the self which is being actualized? What are characteristics? Can we know what sort of self will be actualized beforehand or only ex post facto? Does this become a fancy any of begging questions of motivation by ascribing inevitability of whatever takes place? At its worst, the concept self-actualization can take on a fuzzy, mystical kind of haze. This was true of discussion self-actualization within "humanistic psychology", more recently, Kohut's references to personal "destiny" and Winnicott, s sometimes reified discussions the "true self" take on that same quality.

Allen Rence (2012) assessed gender differences in self-actualization among sample of black university student, black female university students reported more self-actualization than black males. Schindler and Waters (1986) measured self-actualization differences using POI between sexes and different degrees of athletic involvement for college students. It was generally found that women were more self-actualizing than men were.

The present investigation was carried out to examine the impact of sex, place of living and medium of teaching on self-actualization college students.

\section{OBJECTIVES}

1. To measure the difference of self-actualization between male and female college students. 
2. To measure the difference of self-actualization between hostel living and home living college students.

3. To measure the difference of self-actualization between Guajarati medium and English medium college students.

4. To measure the effect of sex, place of living and medium of teaching on selfactualization.

\section{METHOD}

\section{Sample -}

The total sample consisted of 320-college students selected randomly from various colleges of Rajkot district. Out of 320 students, 160 are male and 160 are female. In subject of 160 out of which 80 are hostel living and 80 are home living college students and then in subject of 80 out of which 40 Guajarati medium and 40 English medium college students.

\section{Tools -}

The following tools were used in the present study.

1. Personal data sheet -Personal data sheet was prepared to collect some personal information about name, sex, types of living place, type of teaching medium, city name, district name, etc.

2. Self-actualization inventory -

According to research purpose "self-actualization" measure is used which is invented by Sharma K.N. (2000), which includes 75 statements, checked by 3 point. The test retest reliability of whole test was .85 and validity of this inventory is high.

\section{Procedure -}

Above-mentioned devices were administered to all selected male and female college students having different place of living and medium of teaching. Scoring was carried out as per the manual. To test the framed hypotheses related to self-actualization with reference to type of sex, type of living place and type of teaching medium F-test was used.

\section{RESULT AND DISCUSSION}

The purpose of the present study was to investigate whether "self-actualization among college student: A study with reference to sex, place of living and medium of teaching". To examine the framed hypothesis F-test was applied and the obtained results are presented in the following table- 2 and 3. 
Table No. 1, ANOVA summary of self-actualization with reference to type of sex, place of living and medium of teaching (N-320)

\begin{tabular}{|c|l|l|l|l|}
\hline Variables & \multicolumn{1}{|c|}{ SS } & \multicolumn{1}{c|}{ df } & \multicolumn{1}{c|}{ MS } & \multicolumn{1}{c|}{$\mathrm{F}$} \\
\hline $\mathrm{A}_{\mathrm{SS}}$ & 1570.88 & 1 & 1570.88 & $8.63^{*}$ \\
\hline $\mathrm{B}_{\mathrm{SS}}$ & 4.76 & 1 & 4.76 & $0.03^{\text {ns }}$ \\
\hline $\mathrm{C}_{\mathrm{SS}}$ & 1906.14 & 1 & 1906.14 & $10.47^{*}$ \\
\hline $\mathrm{AB}_{\mathrm{SS}}$ & 3574.90 & 1 & 3574.90 & $19.64^{*}$ \\
\hline $\mathrm{AC}_{\mathrm{SS}}$ & 4090.03 & 1 & 4090.03 & $22.47^{*}$ \\
\hline $\mathrm{BC}_{\mathrm{SS}}$ & 3420.33 & 1 & 3420.33 & $18.79^{*}$ \\
\hline $\mathrm{ABC}_{\mathrm{SS}}$ & 7604.06 & 1 & 7604.06 & $41.78^{*}$ \\
\hline $\mathrm{W}_{\mathrm{SS}}$ & 56784.37 & 312 & 182.00 & \\
\hline $\mathrm{T}_{\mathrm{SS}}$ & 78955.43 & 319 & & \\
${ }^{*} 0.01=6.78$ \\
$* *=$ Not Significant
\end{tabular}

Table No. 2, Difference mean scores of self-actualization with reference to type of sex, place of living and medium of teaching

\begin{tabular}{|c|l|c|c|c|c|}
\hline $\begin{array}{r}\text { Sr. } \\
\text { No. }\end{array}$ & Variables & Categories & $\mathrm{N}$ & Mean & Difference \\
\hline $\mathrm{A}$ & Sex & $\mathrm{A}_{1}$ & 160 & 171.04 & 4.24 \\
\hline & $\mathrm{A}_{2}$ & 160 & 175.48 & \\
\hline $\mathrm{B}$ & $\begin{array}{l}\text { Medium of } \\
\text { teaching }\end{array}$ & $\mathrm{B}_{1}$ & 160 & 175.70 & 4.88 \\
\hline & & $\mathrm{B}_{2}$ & 160 & 170.82 & \\
\hline
\end{tabular}

Hear $-\mathrm{A}=$ Type of sex

$\mathrm{B}=$ Type of teaching medium

Result could be easily understood in graph below - 


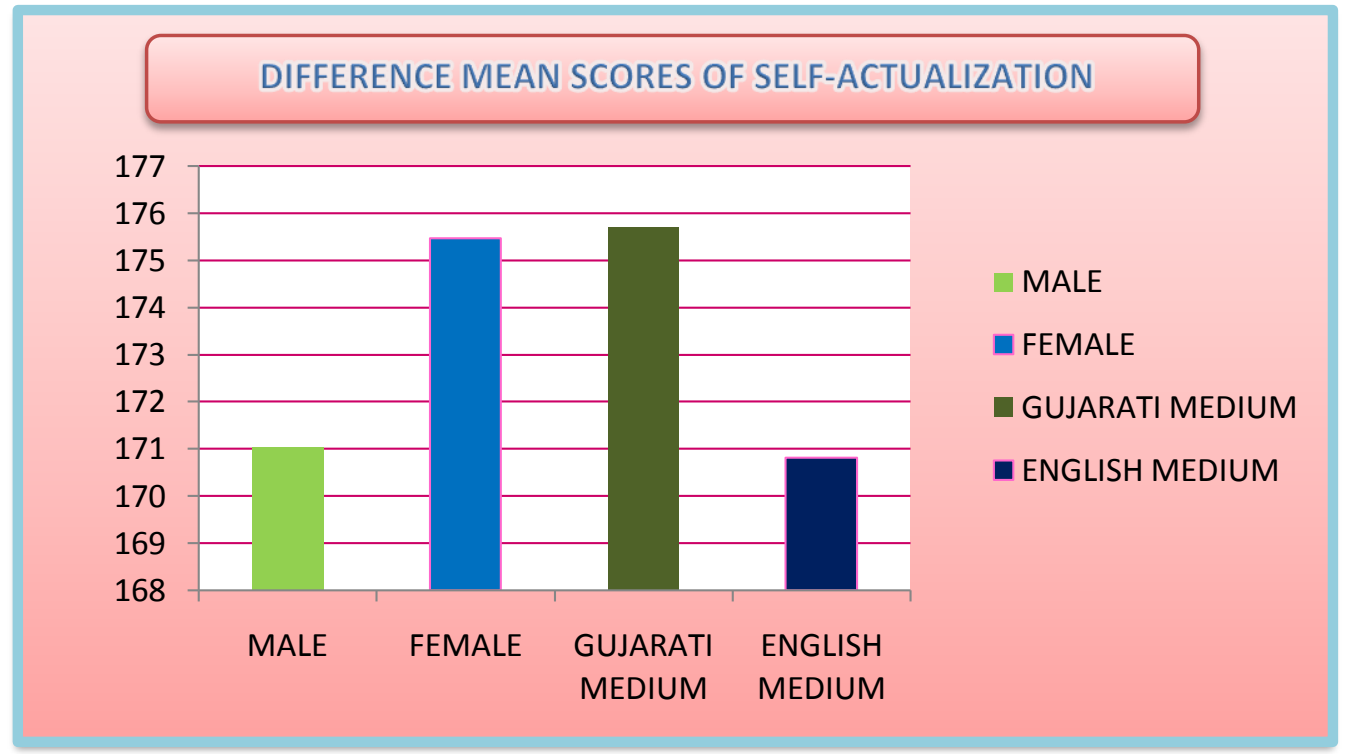

\section{Self-actualization with reference to sex -}

F-test has been applied to measure the impact of sex, place of living and medium of teaching on self-actualization. The F ratio for type of sex is 8.63 (as in Table no.1), which is significant at the level of .01. Study shows that, the mean scores of self-actualization of male and female college students are 171.0 and 175.48 respectively. The difference in self-actualization among these two is (4.24). Means reveal that male college student have less self-actualization than female college students. It can be concluded that sex of college students plays significant impact on selfactualization.

The probable reason for difference of self-actualization behavior of male students is less than girl self-actualization behavior. Male college students have tendency that the college life is golden time for fun while female college students are more conscious about their study and goals. It is found that, due to egoistic and overconfident nature of male college student, they don't accept people, situation and reality as they are and they have misconception of knowing everything, due to these male students have less self-actualization then female college students.

\section{Self-actualization with reference to place of living -}

The F-ratio for types of place living is 0.03 as in Table No.1, which is not significant. Since the hostel, living and home living college students both are living in the same city, and there is no significance different in their living atmosphere and surrounding. Thus it can be concluded that the impact of place of living among college students on self-actualization has no significant role.

The probable reasons for no any difference of self-actualization of hostel living and home living college students; because both are live in city, so atmosphere of city is same. 


\section{Self-actualization with reference to medium of teaching -}

The $\mathrm{F}$ ration for type of medium of teaching is 10.47 as shown in Table No.1, which is significant at the level of .01. Table No.3 shows that the mean scores of self-actualization among the Guajarati medium and English medium college students are 175.70 and 170.82 respectively, the difference between these two is 4.88. Means reveal that Gujarati medium students have greater self-actualization than English medium college students.

The probable reason for difference of self-actualization of Gujarati medium students is grater then English medium students, as we have discussed earlier they both are living in the same society and same city. They both have same mother tongs and due to that, Gujarati medium students need not to additional time and vocabulary for understanding subjects and language, while English medium students have less understanding and feeling of the language.

\section{Self-actualization with reference to interactional effect of sex, place of living and medium of teaching-}

When $\mathrm{F}$ test was applied to examine the interactional effect of sex, place of living and medium of teaching on self-actualization, significant impact was found. The F ratio for ABss, ACss, BCss and ABCss (sex and place of living, sex and medium of teaching, place of living and medium of teaching and sex, place of living and medium of teaching in interactional effect on selfactualization are 19.64, 22.47, 18.79 and 41.78 as shown in Table No.1, which is significant at the level of .01. It was concluded that there was significant interactional impact of sex, place of living and medium of teaching on self-actualization.

\section{CONCLUSION}

As for as male and female college student both are significantly difference in self-actualization, that means male self-actualization are less than female college students. As for as hostel of living and home of living college student both aren't significant difference about selfactualization, that means place of living do not impact on self-actualization. As for as Guajarati medium and English medium college student both are significant difference about selfactualization, that means medium of Gujarati self-actualization are greater than medium of English college students. 


\section{REFERENSE}

1. Allen Rence, et.al. (2012). Gender deference in self-actualization in crystal fence chambers, Rhonda voshay shaped (Ed.) black female undergraduates on campus: successes and challenges, emerald group publishing ltd, pp.-59-75.

2. Daavidson, W.B., bromfieds J. M., Back H. P. (2007). Beneficial academic orientations and selfactualization of college students. Department of psychology and sociology, ASU station no. 10907. Amgelo, State University, Sum Angelo, TX 76909, USA.

3. Frank (1963). Nature and human nature, N. J. Rutgers University Press, New Brunswick.

4. Hah \& Yang (1994). RID 2006,JNS/1994.24.3.499 \& DT=1.

5. Lewis, J. D. (1996). Scores on self-actualization for gifted junior high school students. Psychological reports, 79(11): 59-64.

6. Maslow A. H. (1968). Motivation and personality, New Year: Hareer.

7. Maslow, A. H. (1959). Motivation and personality, JJ>Harper \& Row.

8. Mitchell,S (1990). Goldstein: an appreciation, contemp. Psychoanalyst, 25:616-620.

9. Schindler,T.M. \& Waters, M. (1986), Athletic involvement and aspeotes of self-actualization, journal of sport behavior, 9(2): pp. 56-69.

10. Sharma K.N. (2000). Self actualization inventory-SEAI (2000), lucknow; ankur psychological agency.

11. USAID (2012). Youth in development: realizing the demographic opportunity

Washington D.C.USAID: retrieved from. 